\title{
A SYNTHESIS OF RESEARCH ON TRAINING OF UNION DELEGATES
}

\begin{abstract}
Through several surveys we find that union training and education is important to boost delegates' confidence and activism. Quality, breadth and coverage all matter. Union training should be conceptualised broadly and include what happens outside and after the classroom, both formally and informally. The results raise important practical challenges including structural questions for unions.
\end{abstract}

\section{Introduction}

Effective union education and training is often seen as essential for increasing worker and union power and participation in the workplace (Crosby, 2005; Greene and Kirton, 2002; Zammit, Rizzo and Vancell, 2003). Yet there are many uncertainties about union training that affect the way we understand it theoretically, as well how unions allocate and deploy resources to it. This paper focuses on addressing two significant questions. One is theoretical: how should we conceptualise the role of training and education in the context of debates about union renewal? The second is more practical: does training and education make a difference in terms of skills, confidence and activism and if so, in what ways? 
The authors, often in collaboration with other researchers, have been engaged in research in Australia on a range of matters relating to union organising, growth and training for over a decade. This paper draws on this research to focus on critical issues for union education and training, particularly in relation to workplace delegates (also known as workplace representatives or shop stewards). It makes use of qualitative research involving focus groups with delegates and quantitative research from six surveys of delegates over a period of nine years. We investigate a number of issues regarding the content of and relationship between formal and informal union training and the links to delegate activism. As the research on which this article is based was conducted in Australia, we commence with a brief Australian background. After then describing the data sources, we discuss key findings under six headings, before concluding.

\section{Background}

The period covered by these studies was one of upheaval and restructuring. For most of the $20^{\text {th }}$ century Australian wage fixing had centred around tribunals and, in many cases, workplace activism was not a necessary condition for union members to receive the benefits of union successes within the system. All this changed in the early 1990s when the focus changed from 'awards' of tribunals to locally negotiated 'enterprise agreements' as the basis for wage increases. As the Australian wage system changed, so did demands on delegates. Although unions were pivotal in the shift to enterprise bargaining in Australia (Briggs, 2001), they also recognised in the 1990s that delegates were not adequately skilled for that shift. In 1995, nearly half of delegates reported that 
their skills for the negotiation of an enterprise agreement were either 'really not good enough' or 'non-existent' (Morehead et al 1997:169). By the mid to ate 1990s the Australian Council of Trade Unions (ACTU) had recognised the need to redirect skills and resources to the workplace to cope with this new wage system, and established a specialist unit to promote the adoption of 'organising' approaches within constituent unions. A hostile conservative government, led by Prime Minister Howard, came to office in 1997 and made it harder for unions to regulate or even access workplaces, particularly from early 2006 when radical industrial relations reforms (known as 'Work Choices') were enacted. That government was defeated in late 2007 following a major union campaign (Muir, 2008), but the incoming Labor government maintained several of the legal provisions that made workplace access difficult for paid union officials, highlighting the continuing importance of developing union capacity and activism amongst members within workplaces.

As various unions, not just in Australia but also in other Anglophone countries (Frege \& Kelly, 2003), attempted a transition to an 'organising' approach, the importance of training and education of members was stressed by a number of authors (Carter \& Cooper, 2002; Conrow \& Delp, 1999; Cooper, 2001; Crosby, 2002, 2005; Grabelsky \& Hurd, 1994; Griffin \& Moors, 2004; Kumar \& Schenk, 2006). Training refers to the acquisition of skills (such as grievance handling and bargaining) whereas education refers to affecting how members think 'to develop their capacities for critical thinking and strategic analysis over the entire range of issues for working people' (Eisenscher 2001, cited in Kumar \& Schenk 2006). Since the late 1990s, a growing feature of union strategy has been putting resources into the training and education of workplace union delegates. By 2004, 62 per cent of delegates in a survey had received some form of 
union training, and less than 10 per cent of delegates rated their confidence in their abilities to answer queries or participate in meetings or campaigns as low (either 1 or 2 on a scale of 1 to 5) (unpublished data from Peetz and Pocock 2009).

If union delegates and activists are to successfully organise collective action then, under mobilisation theory (Kelly 1998), they need to be able to highlight injustice, frame a definition of collective interest, successfully attribute blame to employers, legitimise and organise mobilisation and respond to counter-mobilisation by employers; to varying degrees, delegates require training in the skills needed to achieve each of those steps. As Kumar and Schenk (2006) point out, it is widely believed that 'an accelerated program of education and training of rank and file members is needed to facilitate internal reform and, perhaps more importantly, leadership development'. Some highlight that the changed role of the workplace delegate and the new expectations placed on members can generate resistance, and prevent uptake of the new approach, if reasons behind the changes are not well explained. Others have cautioned that moves to implement an organising approach through a top-down approach of educating members that does not also entail a fundamental realignment of the relationship between members and union officials 'has the potential to simply push union functions downward, burn out activists and possibly see union effectiveness decline further' (Cooper, 2002, p. 135). By this logic, unions would need to ensure that members and activists have to 'own' the new approach (Bronfenbrenner \& Hickey, 2004; Fletcher \& Hurd, 1998). Some authors, using largely qualitative research, have indicated that union education is more important for building up confidence than skills (Greene and Kirton, 2002). But this needs further, quantitative investigation and many other important questions are unanswered. The key issues we investigate include: what is the 
relationship between formal and informal union training? In what ways does union training shape delegate activism? What matters most in union training? What aspects of union training succeed, or fail, in achieving union objectives? As the research on which this article is based was all conducted in Australia, we commence with the Australian background: why is union training important in Australia, and how does it relate to activism and the institutional changes that have taken place there?

\section{Data sources}

Our data come from several sources, but most important are two major studies. The first was the Australian Workplace Industrial Relations Survey (Morehead et al 1997), undertaken in 1995 (AWIRS95), not long after after the institutional shift to 'enterprise bargaining'. The analysis from AWIRS95 utilises the delegate survey interviews undertaken at 1138 of the 2004 workplaces with 20 or more employees that participated. The second study was an Australian Research Council (ARC)-funded project conducted by one of the authors along with with Barbara Pocock, investigating issues of representation and organising within Australian unions - the Representation and Organising Research Project (RORP). The RORP study was conducted from 20022004 , over a decade after the shift to enterprise bargaining, half way into the more hostile Howard Government era and a few years after the ACTU had adopted in principle the idea of moving to more organising approaches. It contained a number of components, including: a survey of 379 organisers from 13 unions (Peetz, Houghton and Pocock 2005); a survey of 2506 delegates from eight unions (Peetz \& Pocock 2009), focus groups with 60 delegates from the same eight unions (Clarke, Pocock \& Peetz 
2005); and a survey of leaders from 13 unions. The survey of delegates from eight unions is the most heavily utilised in this paper amongst those. While the AWIRS delegates surveyed were the 'most senior' delegate in their workplace, in RORP delegates were randomly sampled.

The analyses are complimented at times with: work previously undertaken in 2000 that utilises a survey of 852 delegates from the Finance Sector Union (FSU) and a follow-up survey in 2001 of 102 of delegates from the same union who had completed a delegatetraining course (see Peetz, Webb \& Jones 2002 for details); a 2008 survey of 216 former participants in ACTU Education and Campaign Centre (ECC) delegate training ; and a 2009 survey of 199 members and delegates from an anonymous union ('Union A') who had been through union training courses. These last two took place after the defeat of the Howard government and in a period when the notion of organising was well established within significant parts of the union movement, though far from universally.

The surveys differ in the information they collected about training, but mostly did not differentiate between types of training. AWIRS95 and, more extensively, RORP collected information on the topics covered by training; these are listed in the discussion on breadth of training, below. RORP collected information on when training most recently took place and its perceived effectiveness. No survey sought to distinguish between 'training' and 'education', a distinction that would have been difficult for some delegates to make. In the discussion that follows, then, we use the term 'training' to cover both training and education. Also, no differentiation was made between different methods of formal training (eg face-to-face versus mixed mode, one- 
day versus three day, week-day versus weekend) - these remain matters for further research - although we do make some points about the relationship between formal and informal training below.

\section{What is the significance of union training? Training, tenure and confidence}

It might be thought that the most important thing for delegates to have is experience in the role itself. Indeed, our data indicate that tenure (length of time) as a delegate improves delegates' confidence. However, this view underestimates the benefits of training and exaggerates the relative benefits of tenure.

In the FSU study (Peetz, Webb \& Jones 2002), training was found to significantly increase various measures of activism, whereas tenure's impact was only marginally significant for some measures of activism. That study also found that increasing the skill of delegates only enhances delegate activism through its effect on confidence - that is, increasing skill without increasing confidence had no benefits for activism. The impact of training on activism was greater than could be explained simply by improvements in skill and confidence. This might reflect the role of 'education' beyond 'training', with the greater breadth of courses exposing delegates to broader issues affecting workers and to analytical and strategic approaches, possibly enhancing the motivation of participants to effect change, but as previously noted we have no data distinguishing between training and education. 
In AWIRS95, the skills of a delegate were measured on a four-point scale ( $\mathrm{min}=1$; $\max =4$; mean $=2.8$ ) based on the sum of their own assessment of their skill level in handling 6 different issues. In RORP, it was the confidence of the delegate that was measured on a five-point scale, based on the delegate's assessment of how confident they felt across three key abilities ( $\min =1 ; \max =5$; mean=4.0).

We regressed confidence or skills against indexes of delegate training in AWIRS95 and the RORP delegates survey, based on the number of issues from a predetermined list for which training had been received, and the length of time delegates had been in the role (tenure). This multivariate analysis tells us that each increase in the AWIRS95 training index (attending one additional course from six considered) had an impact on a delegate's skill index of 0.063 (see column (1)). Each unit increase in the training index was equivalent to that resulting from 5.6 years of experience in the role. This suggested that training courses would be a more time-effective way for delegates to develop the necessary skills than simply learning from experience. Similarly in RORP, the impact of training was statistically more significant than tenure as a determinant of confidence (see column (2)), such that it took 3.2 years of tenure to have the same effect as one additional training course. Further testing also indicated that training was as helpful in enhancing the confidence of long-term delegates as it was to new delegates. 


\begin{tabular}{|l|c|c|c|}
\hline & $\begin{array}{c}\text { (1) } \\
\text { Skills } \\
\text { (AWIRS95) }\end{array}$ & $\begin{array}{c}\text { (2) } \\
\text { Confidence } \\
\text { (RORP) }\end{array}$ & $\begin{array}{c}\text { (3) } \\
\text { Confidence } \\
\text { (RORP) }\end{array}$ \\
\hline Constant & $\begin{array}{c}1.460^{* * *} \\
(38.74)\end{array}$ & $\begin{array}{c}3.569^{* * *} \\
(135.21)\end{array}$ & $\begin{array}{c}3.844^{* * *} \\
(70.67)\end{array}$ \\
\hline Tenure & & & $0.129^{* * *}$ \\
(per 5 years) & $0.056^{* *}$ & $\left(8.133^{* * *}\right.$ & $0.058^{* * *}$ \\
\hline Training index & $(3.16)$ & $0.086^{* * *}$ & $(6.30)$ \\
(per issue) & $0.063^{* * *}$ & $(13.85)$ & $-0.371^{* * *}$ \\
\hline Usefulness of training & $(7.18)$ & & $(-7.51)$ \\
Rating: Not useful (1) to & & & $-0.118^{* *}$ \\
(3) & & & $(-2.90)$ \\
\hline Usefulness of training & & & 0.113 \\
Rating: (4) & & & 1542 \\
\hline Usefulness of training & & & \\
Rating: Very useful (5) & & & \\
(ref) & & & \\
\hline Joint F-test (df=2,1537) & & & \\
\hline Adjusted R2 & & & \\
\hline N & & & \\
\hline Usefulness of training & & & \\
\hline
\end{tabular}

Source: RORP delegate survey

Notes: The table shows the marginal effect of each variable on the confidence index for the units shown in the left hand column. The marginal effects were significant at $1 \%\left({ }^{* *}\right)$ level and $0.1 \%$ ( $^{* * *}$ ) level, with t-statistics shown in parentheses. 
We also wanted to examine the impact of tenure, training and skills or confidence on delegate activism, as unions ultimately seek to promote activism for union renewal. So we considered three different measures of activism from each of the AWIRS95 and RORP delegate surveys and regressed each against tenure, training, and confidence or skills. The measures of activism are explained in the notes to Table 2, but in brief they refer to the number of union-related activities delegates undertake, the amount of time they spend on them, the contact they have with other delegates, and their own selfperception of their involvement in the union. Activism was best predicted by perceived skills or confidence, and also by training, but not as well by tenure, suggesting that experience on the job (tenure) was the least important of these three concepts for improving delegate activism. Across all three measures of activism in each analysis, the largest and most significant association (the highest t-statistic) was with the effect of skills (AWIRS95) or confidence (RORP delegate survey). A measure of the number of issues in which delegates were trained was also highly significant across all measures of activism. The effect of tenure, on the other hand, was much smaller statistically - in fact it was only significant in two of three AWIRS95 measures and in none of the three RORP delegate survey measures (see Table 2).

We also found in several of these studies that, to the extent that gender differences existed, they related to differences in confidence. Women have less confidence than men across a wide range of matters (Lenney, 1977) and this may be attributed in no small part to differences in socialisation (Hackett and Betz, 1981). In the FSU survey we found that women delegates were less likely to be have been trained, less confident than men and had lower assessments of their own skill levels. On most measures of activism, any lower activism by women was due to lower training and their workplace 
location (Peetz, Webb \& Jones 2002). In the RORP delegate survey, women again were less confident than men. Women were less activist delegates than men, but this was easily explained by differences in confidence and, to a lesser extent, in access to training.

Overall, it appeared that training and tenure both boosted delegate confidence, and through this boosted activism. In the case of tenure, almost all of the activism effects occurred through impacts on confidence, but training had other consequences that also boosted activism. 
Table 2 Delegate activism and tenure, training and skills/confidence

\begin{tabular}{|c|c|c|c|c|c|c|}
\hline & \multicolumn{3}{|c|}{ AWIRS95 } & \multicolumn{3}{|c|}{ RORP } \\
\hline & $\begin{array}{c}\text { Breadth of } \\
\text { activism }\end{array}$ & $\begin{array}{l}\text { Depth of } \\
\text { activism }\end{array}$ & $\begin{array}{c}\text { (Ln) Union } \\
\text { hours }\end{array}$ & $\begin{array}{c}\text { Number of } \\
\text { Tasks }\end{array}$ & $\begin{array}{c}\text { Intra- } \\
\text { delegate } \\
\text { contact }\end{array}$ & $\begin{array}{c}\text { Involveme } \\
\text { nt in union } \\
\text { activities }\end{array}$ \\
\hline Constant & $\begin{array}{l}2.783^{* * *} \\
(8.06) \\
\end{array}$ & $\begin{array}{l}0.913^{* * *} \\
(3.93)\end{array}$ & $\begin{array}{c}-0.157 \\
(-1.55) \\
\end{array}$ & $\begin{array}{l}1.247^{* * *} \\
(9.02) \\
\end{array}$ & $\begin{array}{l}0.988^{* * *} \\
(8.26)\end{array}$ & $\begin{array}{l}0.808^{* * *} \\
(8.20) \\
\end{array}$ \\
\hline $\begin{array}{l}\text { Tenure } \\
\text { (per } 5 \\
\text { years) }\end{array}$ & $\begin{array}{l}0.394^{* * *} \\
(4.48)\end{array}$ & $\begin{array}{c}0.101 \\
(1.09)\end{array}$ & $\begin{array}{l}0.100^{* * *} \\
(3.34)\end{array}$ & $\begin{array}{r}-0.045 \\
(-1.80)\end{array}$ & $\begin{array}{r}0.032 \\
(1.50)\end{array}$ & $\begin{array}{r}0.004 \\
(0.24)\end{array}$ \\
\hline $\begin{array}{l}\text { Training } \\
\text { (per issue) }\end{array}$ & $\begin{array}{l}0.251^{* * *} \\
(4.67)\end{array}$ & $\begin{array}{l}0.162^{* * *} \\
(3.99)\end{array}$ & $\begin{array}{l}0.060^{* * *} \\
(3.84)\end{array}$ & $\begin{array}{l}0.063^{* * *} \\
(7.31)\end{array}$ & $\begin{array}{c}0.076^{* * *} \\
(10.21)\end{array}$ & $\begin{array}{c}0.072^{* * *} \\
(11.79)\end{array}$ \\
\hline $\begin{array}{l}\text { Skills/ } \\
\text { Confidence } \\
\text { (per index } \\
\text { unit) }\end{array}$ & $\begin{array}{l}1.737^{\text {*** }} \\
(7.33)\end{array}$ & $\begin{array}{l}0.660^{* * *} \\
(4.60)\end{array}$ & $\begin{array}{l}0.386^{* * *} \\
(6.01)\end{array}$ & $\begin{array}{c}0.689^{* * *} \\
(18.91)\end{array}$ & $\begin{array}{l}0.541^{* * *} \\
(17.17)\end{array}$ & $\begin{array}{l}0.592^{* * *} \\
(22.73)\end{array}$ \\
\hline $\mathrm{R}^{2}$ & 0.215 & 0.087 & 0.115 & 0.180 & 0.195 & 0.292 \\
\hline $\mathrm{N}$ & 1081 & 1081 & 1076 & 2498 & 2494 & 2337 \\
\hline
\end{tabular}

Source: AWIRS95 union delegate questionnaire and RORP delegate survey

Notes: The table shows marginal effects of each variable for the units shown in the left hand column. For the breadth and depth regressions, marginal effects are the change in the number of tasks. For the regression of the natural logarithm of union hours, marginal effects are the percentage change in union hours.

Items: 'Breadth of activism' measures delegate activism by a count of how many of these tasks a delegate indicated they did $(\min =0 ; \max =12$; mean $=6.7)$.

'Depth of activism' counts how many items from this same list a delegate indicated they 'spent a lot of time on' (min=0; $\max =12$; mean=2.5).

'(Ln) Union hours' is (the natural logarithm of) the average number of hours per week delegates said they spent on union activities, to the nearest whole hour (actual hours min $=0$; $\max =70$; mean=3.8).

'Number of tasks' is based on questions asking which of six specific tasks they had undertaken in the previous six months and is the number of these tasks that a delegate performed. (min=0; max=6; mean=4.1). This is similar to the breadth measure of activism in AWIRS95

'Intra-delegate contact' measures the amount of contact that delegates had with other delegates, both within their own workplace and elsewhere, and with delegates from their own union and from other unions. The measure is an index based on three 5-level items that measure delegates' agreement that they had a lot of contact with: other delegates at the workplace; delegates from the same union at other workplaces; and delegates from other unions $(\min =1 ; \max =5$; mean=3.4).

'Involvement in union activities' measures responses on a 5-point scale to the statement 'I feel that I am very involved in union activities' ( $\min =1 ; \max =5$; $\operatorname{mean}=3.4$ ).

Key: marginal effects significant at the $0.1 \%(* * *)$ level, if indicated.

t-statistics shown in parentheses. 


\section{What is the relevance of the quality of training?}

Not all training is beneficial. If training is going to improve confidence, it must be perceived by delegates to be useful for their roles. The RORP data indicated that perceived usefulness of training (for those who had undertaken some) was an important aspect of the impact of training on confidence. Less useful training reduced the benefit of additional training: a poor rating on the usefulness of training more than offset the positive aspects of training on confidence. This is indicated in column (3) of Table 1. Delegates were asked to rate all of training they had received on a five-point scale from (1) 'not at all useful' to (5) 'very useful'. Compared to cases where all the training was useful (rating 5), column (3) of Table 1 shows that the confidence index was lower by 0.118 when the rating was four - equivalent in magnitude to the average effect of participating in two fewer training courses - and if was rated as three or less, the benefits of training were effectively wiped out, even where six courses had been undertaken. Similarly, the perceived usefulness of training was strongly correlated with activism.

We divided delegates in RORP into three comparably sized based on their scores on the scale measuring their confidence categories (high, medium and low confidence). Delegates who rated their training 'very useful' were in the 'high confidence' category 46 per cent of the time, compared to 33 per cent of those who rated the training 'somewhat useful' or lower (Figure 1). Similarly, delegates who rated their training 'very useful' were more likely to be in a high activism category or in a high 'local union power' category (52 per cent being in this high power category, based on an index of 
responses to four questions, compared to 33 per cent of the rest) (for the power index see Peetz \& Pocock 2009).

'Usefulness' of training translated into better outcomes where lessons were put into practice. In the survey of ECC trainees, those who rated training as most useful were most likely to say that union success had gone up "a lot" in their workplace. Where delegates reported that the course changed the way they carried out their role and put the ideas or lessons from training into practice, they were $3 \frac{1}{2}$ times more likely to report member success had gone up 'a lot' than if they had not changed the way they did things due to training.

\section{Figure 1: Relationship between the perceived usefulness of training and confidence, activism and perceived power}
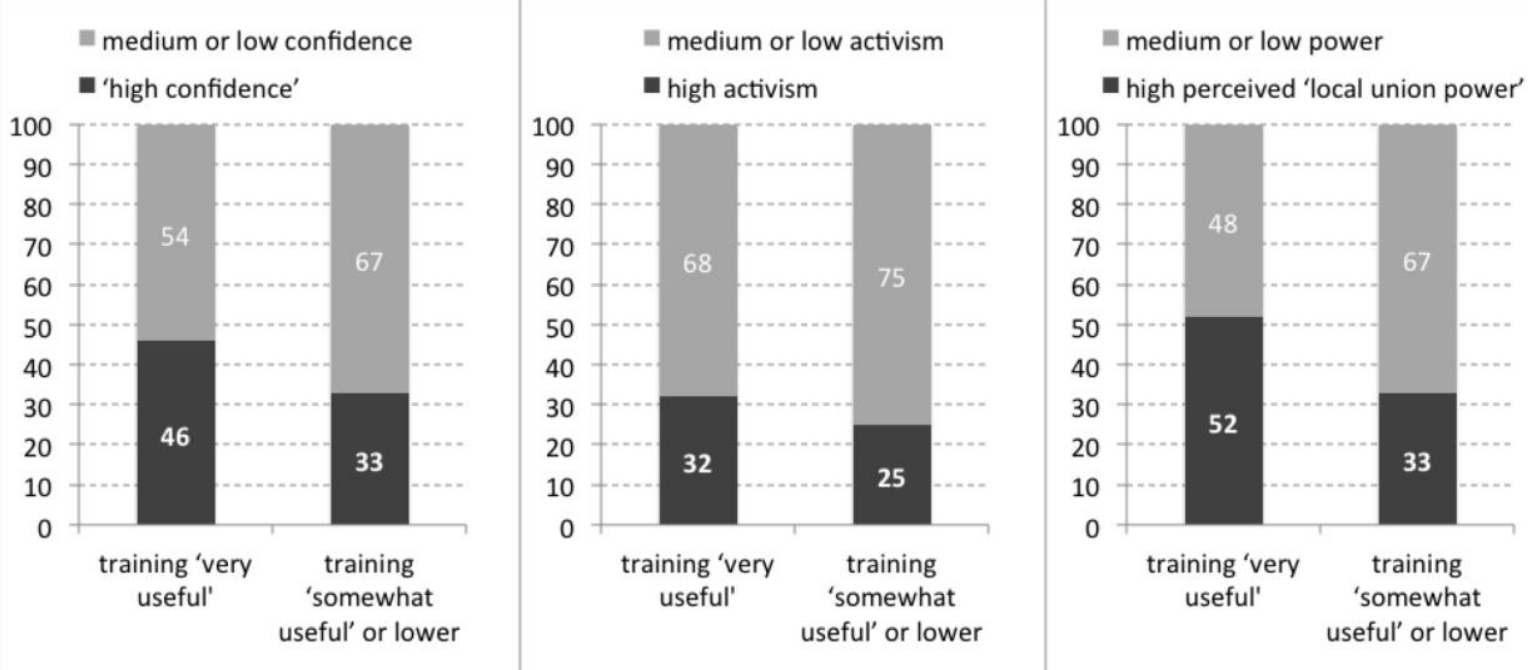

Source: RORP delegate survey

We interpret the pattern of findings in this section and the previous as indicating that delegate education and training have effects on confidence over and above the skills taught. Good training provides delegates with ideas, motivates them, inspires them and 
gives them a sense of collective identity and power. It also gives them a space and opportunity to reflect on their world - understand it better and consider how they can act to change it.

One other, very important implication of these findings is that the relationship between training and activism cannot simply be explained away as reverse causality.

A common initial reaction amongst some union officials when we present data linking undertaking of training to confidence and activism is to think that this just reflects reverse causality: individuals who are more activist are simply more likely to choose to take training. But this is only part of the story. We accept that activists are more likely to seek training. But in unions, training is not just driven by demand. It is also driven by supply - what the union provides, to how many, how often and how well.

If reverse causality dominated, and training had no impact on activism, then the quality of training would also have no independent impact on outcomes. Yet we have just seen that the quality of training of training significantly affects confidence, activism and power.

We can also test the reverse causality hypothesis another way - by examining people who we can identify as being more motivated towards activism. If reverse causality explained our earlier findings, then this group (one might term them 'innate activists') would be more likely to be trained, but training would not affect their activism or local union power. Untrained delegates who were innate activists would be more activist in the union than trained delegates who were not innate activists. 
Our proxy for innate activists is people who are activists outside the union. People who hold an activism position in a social group, community association or other external body (other than the union), accounted for 13 per cent of our delegates in RORP. We call these innate activists 'community activists'. They are likely to have attitudes and experiences that facilitate them being activist independent of becoming a delegate.

It is true that community activists were more likely to be trained than other delegates. Yet amongst delegates without training, we found that community activists were no more activist in the workplace than union-only delegates - in both categories, only 14 per cent of delegates could be classified in the 'high activism' category. Amongst community activists who had received training, however, 37 per cent were in the 'high activism' category. Amongst 'union-only' delegates who had been trained, 26 per cent were classified as having 'high activism'. This is higher than activism amongst untrained community activists, and is the opposite of what would be predicted under the reverse causality hypothesis. The higher level of union activism amongst community activists only occurred amongst those who had been trained. The benefits of training were even greater amongst community activists than amongst other delegates. But without training, the greater potential for activism that is brought to the union by people with outside activist experience is lost.

Similarly, community activist delegates who were untrained reported no higher perceived local union power than did other untrained delegates, but training led to greater perceived power amongst both groups, with the increase greater for community 
activists. To summarise: Quality matters. Better quality training leads to higher confidence and activism

\section{What is the relevance of the breadth and content of training?}

As noted above, the number of issues in which delegates were trained (the training index) was linked to confidence and activism. We sought to unpack that index, to consider what types of training might be most associated with activism. We found that the training issues most associated with delegate activism across the two major surveys concerned enterprise negotiations and/or campaigning and networking. In RORP, correlation analysis indicated the strongest links with activism comprised training in enterprise bargaining, developing union networks and structures and campaigning skills (Table 3). Regression confirmed the primacy of these variables. Interestingly, these last two (networking and campaigning) were the training issues least likely to have been undertaken by delegates. 
Table 3 Correlation between delegate activism and undertaking training on particular issues

\begin{tabular}{|c|c|c|c|c|}
\hline Issue & $\begin{array}{c}\text { Training } \\
\text { undertaken }\end{array}$ & $\begin{array}{l}\text { Number of } \\
\text { tasks }\end{array}$ & $\begin{array}{c}\text { Intra- } \\
\text { delegate } \\
\text { contact }\end{array}$ & $\begin{array}{l}\text { Involvement } \\
\text { in union } \\
\text { activities }\end{array}$ \\
\hline & $\%$ & $\rho$ & $\rho$ & $\rho$ \\
\hline Training index & NA & $0.249^{* * *}$ & $0.304^{* * *}$ & $0.359^{* * *}$ \\
\hline Enterprise bargaining & 34.4 & $0.193^{* * *}$ & $0.269^{* * *}$ & $0.309^{* * *}$ \\
\hline Campaigning skills & 28.8 & $0.227^{* * *}$ & $0.257^{* * *}$ & $0.292^{* * *}$ \\
\hline $\begin{array}{l}\text { Developing union networks } \\
\text { and structures }\end{array}$ & 30.2 & $0.191^{* * *}$ & $0.238^{* * *}$ & $0.269^{* * *}$ \\
\hline $\begin{array}{l}\text { Promoting activism and } \\
\text { involvement by members }\end{array}$ & 36.8 & $0.191^{* * *}$ & $0.224^{* * *}$ & $0.281^{* * *}$ \\
\hline $\begin{array}{l}\text { General introductory } \\
\text { training }\end{array}$ & 49.2 & $0.184^{* * *}$ & $0.219^{* * *}$ & $0.268^{* * *}$ \\
\hline Recruitment techniques & 37.7 & $0.184^{* * *}$ & $0.213^{* * *}$ & $0.248^{* * *}$ \\
\hline Grievance resolution & 34.7 & $0.181^{* * *}$ & $0.213^{* * *}$ & $0.248^{* * *}$ \\
\hline Communication skills & 36.3 & $0.146^{* * *}$ & $0.236^{* * *}$ & $0.231^{* * *}$ \\
\hline Managing meetings & 30.6 & $0.179^{* * *}$ & $0.218^{* * *}$ & $0.230^{* * *}$ \\
\hline $\begin{array}{l}\text { Occupational health and } \\
\text { safety }\end{array}$ & 33.3 & $0.170^{* * *}$ & $0.183^{* * *}$ & $0.220^{* * *}$ \\
\hline None & 42.1 & $-0.216^{* * *}$ & $-0.245^{* * *}$ & $-0.311^{* * *}$ \\
\hline
\end{tabular}

Source: RORP delegate survey

$\mathrm{N}$ ranges from 2144 to 2350 .

Notes: $\quad * * * \quad$ Significant at the 0.1 per cent level 
The AWIRS95 study asked about a different range of training issues but the standout associations with activism were negotiating workplace agreements and developing general negotiation/consultation skills (Table 4).

Successful recruitment behaviour depends on developing confidence and skills across a range of delegate competencies, not just in relation to recruitment skills. In RORP, success in recruiting someone to the union within the previous six months correlated significantly, as one would expect, with having been trained in recruitment techniques $(\mathrm{r}=.13)$, but the correlation of recruitment success was even stronger with overall confidence (.21) and with each of its components - confidence in answering queries from members (.16), participating in a meeting of delegates (.18) and being involved in a workplace campaign (.17). It also correlated more strongly with the index of local union power $(\mathrm{r}=.18)$. In the earlier FSU survey, an overall confidence index was also a better predictor of recruitment success than was confidence in recruitment. 
Table 4 Correlation between delegate activism and undertaking training on particular issues

\begin{tabular}{|c|c|c|c|c|}
\hline Issue & $\begin{array}{c}\text { Training } \\
\text { undertaken }\end{array}$ & $\begin{array}{l}\text { Breadth of } \\
\text { activism }\end{array}$ & $\begin{array}{l}\text { Depth of } \\
\text { activism }\end{array}$ & $\begin{array}{c}\text { (ln) } \\
\text { Delegate } \\
\text { hours }\end{array}$ \\
\hline & $\%$ & $\rho$ & $\rho$ & $\rho$ \\
\hline Training index & NA & $0.311^{* * *}$ & $0.241^{* * *}$ & $0.233^{* * *}$ \\
\hline $\begin{array}{l}\text { Negotiating workplace } \\
\text { agreements }\end{array}$ & 37.5 & $0.379 * * *$ & $0.222^{* * *}$ & $0.247^{* * *}$ \\
\hline $\begin{array}{l}\text { Developing general } \\
\text { negotiation/ consultation } \\
\text { skills }\end{array}$ & 45.2 & $0.275^{* * *}$ & $0.219 * * *$ & $0.221^{* * *}$ \\
\hline Union rules and structures & 48.0 & $0.188^{* * *}$ & $0.172^{* * *}$ & $0.135^{* * *}$ \\
\hline $\begin{array}{l}\text { Occupational health and } \\
\text { safety }\end{array}$ & 30.2 & $0.195^{* * *}$ & $0.127^{* * *}$ & $0.169^{* * *}$ \\
\hline $\begin{array}{l}\text { Equal employment } \\
\text { opportunity/ affirmative } \\
\text { action }\end{array}$ & 25.2 & $0.166^{* * *}$ & $0.167^{* * *}$ & $0.133^{* * *}$ \\
\hline Recruitment skills & 19.9 & $0.157^{* * *}$ & $0.172^{* * *}$ & $0.126^{* * *}$ \\
\hline Sexual and racial harassment & 22.6 & $0.157^{* * *}$ & $0.143^{* * *}$ & $0.105^{* * *}$ \\
\hline $\begin{array}{l}\text { None of the above (no } \\
\text { training) }\end{array}$ & 35.2 & $-0.255^{* * *}$ & $-0.177^{* * *}$ & $-0.193^{* * *}$ \\
\hline
\end{tabular}

Source: AWIRS95 main survey

$\mathrm{N}$ ranges from 1081 to 1086.

Notes: $\quad * * * \quad$ Significant at the 0.1 per cent level

These findings do not necessarily imply that only delegates trained across a range of skills should recruit. However, to persuade people to join, unions need to be able to demonstrate power within the workplace. That does not come simply from training 
people in recruitment. Reliance on that alone is attempting to short-circuit several elements linking training and membership growth.

Moreover, some delegates may not like recruiting - there may be others who enjoy it more. From the delegate focus groups (Clarke, Pocock, \& Peetz, 2005), it was apparent that delegates thought it was important to recognise the different skills people had. This included that not everyone was comfortable with recruiting, but some were excellent at it. Recruiting was seen as easier when it was 'like to like'. In one focus group delegates who were highly active were nevertheless quite hostile to the suggestion that they recruit. Several delegates were not recruiters but could identify someone who did this job in their workplace and did it well. Recruiters were able to do union work on the job but less likely to be able to attend meetings held out of hours or away from the workplace; or they may have been happy talking to individuals about joining the union but less interested in participating in group processes.

Delegate activism, then, is influenced by the breadth of training (the quantity) and the relevance and specific type of training. Training in a broad range of skills associated with building member power (such as in campaigning and developing networks) does more to build membership growth and success than training in recruitment alone. In addition, there are issues about the breadth of delegates themselves covered by training. Training success is influenced by whether practice acknowledges the very different preferences, skills and attributes that people bring to the role of delegate. Particularly in medium and larger workplaces, there is scope for promoting the specialisation of roles, or supporting delegates in the different roles they may prefer. 


\section{What happens if there is no follow-up to training?}

The second survey of FSU delegates showed that an important time for contact between delegates and organisers is after training. Delegates who received follow-up contact from organisers after training were more likely to show increased union commitment. And the more frequent the contact, the greater the increase in commitment. Delegates with higher commitment levels had higher activism levels.

The picture was repeated in the 2009 survey of Union A (Table 5). Those who were followed up were slightly more likely to perceive themselves as now more effective at undertaking the tasks covered in the training course than those who were not followed up, but notably more confident and involved in union activities. They reported, more often, increases in success rates amongst their members. The differences in the patterns between variables suggests that the impact of follow-up is not so much on the specific skills covered in the training course as on the linking of those skills to the broader responsibilities of union delegates. 
Table 5 Post-training organiser contact and changes in outcomes, Union A survey

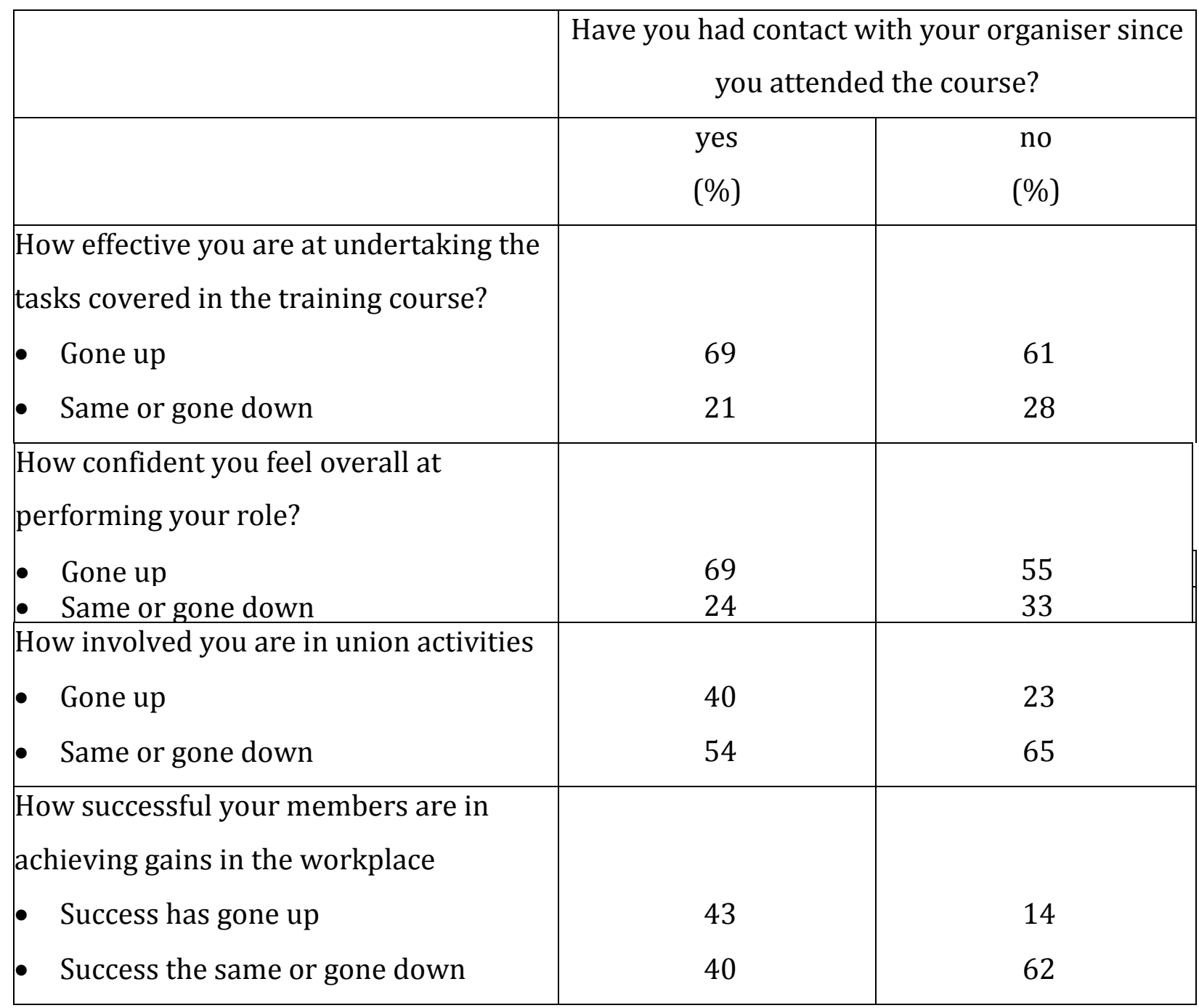

Source: Union A survey, 2009.

In the data from ECC training participants, we were able to separate out those delegates who had themselves initiated contact with the organiser, removing the potential for reverse causality to infect the results. Delegates reported that success had gone up 'a lot' in only 16 per cent of cases where organisers had made no contact with delegates, but in 25 per cent of instances where organisers initiated contact to follow-up the course, and 31 per cent where this had happened and delegates reported that they were 
applying lessons from the course at least once a week. Thus training was most effective when delegates change the way they carry out their role and put into practice the ideas or lessons from the training.

These results have important implications for organisers' skills. They need to be provided with the skills, support, and time to mentor delegates as part of their regular workload. In sum, there is limited value from formal training of delegates if there is not follow-up to their training. Post-training contact with organisers is strongly related to commitment and hence activism

\section{So is there too much emphasis on the formal side of training?}

Follow-up to formal training can be thought of as part of a broader set of activities that can be grouped together under a heading we call 'informal training', which encompasses not only what might be thought of as 'on the job' training of delegates by organisers, but also the more general mentoring of delegates that organisers may undertake. Through this mentoring delegates can learn much that they can apply in the workplace. The RORP delegate survey reveals how important this additional support that may be provided to delegates can be in building their confidence. The top half of Table 6 shows the relationship between delegate confidence and the proportion of delegates who indicated that they received high levels of various forms of contact and support from their organiser or the union office. For example, it shows that, amongst delegates with low confidence, only 8 per cent reported high contact with their organiser (three or more contacts per month), whereas amongst delegates with high confidence, some 33 
per cent reported high contact with their organiser. Likewise confidence was higher where delegates had more contact with other people in the union office and perceived high levels of support from the union office.

The bottom half of Table 6 shows a strong relationship between delegate confidence and each of organiser mentoring and role clarity amongst delegates. It shows for example that, amongst delegates with low confidence, only 14 per cent agreed (or strongly agreed) that their organiser had taught them many valuable things, but amongst those with high confidence some 55 per cent thought their organiser had taught them many valuable things. Likewise only 38 per cent of delegates with low confidence agreed the expectations of their role as a delegate were clear to them, but this was the case for 84 per cent of high confidence delegates.

Not surprisingly, given the relationship between confidence and activism, all of these variables were important in explaining higher levels of delegate activism across all measures, particularly union mentoring and role clarity. These findings were reinforced in the focus groups. Delegates valued organisers who spent time developing delegates' understanding and skills; said one, 'I think the biggest thing for me was not only training but to have a mentor'. 
Table 6 High organiser and union support by delegate confidence

\begin{tabular}{|l|c|c|c|}
\hline & \multicolumn{3}{|c|}{ Index of delegate confidence } \\
\hline & $\begin{array}{c}\text { Low } \\
\%\end{array}$ & Medium & High \\
& & & $\%$ \\
\hline \multicolumn{1}{|c|}{ Percentage of delegates with... } & 7.7 & 14.4 & 32.8 \\
\hline High organiser contact & 16.2 & 24.4 & 43.1 \\
\hline High union office support & 5.1 & 6.8 & 16.2 \\
\hline High union office contact & & & \\
\hline \multicolumn{1}{|c|}{ Percentage of delegates who } & & & \\
\hline $\begin{array}{l}\text { Organiser taught me many valuable } \\
\text { things }\end{array}$ & 13.6 & 31.4 & 55.1 \\
\hline $\begin{array}{l}\text { It is clear what is expected of delegates } \\
\text { (in this union) }\end{array}$ & 38.4 & 60.9 & \\
\hline
\end{tabular}

Source: RORP delegate survey

$\mathrm{N}=$ approximately $750-800$ per category (varies slightly between questions).

The way in which each of these concepts (organiser mentoring, frequency of contact with the organiser and the rest of the union office, the rating of the union office support and role clarity) affected confidence (whilst taking the effects of the other variable into account) is indicated by the multivariate regression of confidence in Table 7 (which builds on the results in Table 1). In the first column of Table 7, all five of these variables are highly significant, with clarity of the delegate role being the most statistically important (with the highest t-statistic). Here, the statistical significance of tenure is now slightly higher than that for training: this reflects the way in which training influences the other variables in the equation. For example, training leads to better role clarity amongst delegates ( $\mathrm{r}=.27)$. Highly trained delegates are more likely to be in frequent contact with their organisers, partly as a result of follow-up, and partly because they are 
more able to take the initiative in contacting organisers. So training is correlated with organiser mentoring $(r=.33)$, frequency of contact with organisers $(r=.29)$ and with the union office $(\mathrm{r}=.20)$ and perceived union support $(\mathrm{r}=.12)$. So it is partly through these effects that training boosts confidence. By contrast, each of those items has a lower correlation with tenure than with training and some (organiser mentoring and perceived union support) have no significant link to tenure. So, training has multifaceted effects on confidence and hence on activism, while tenure's effects are narrower.

Interestingly, the last column of Table 7 shows a regression restricted to those delegates who had undertaken training (hence the $\mathrm{R}^{2} \mathrm{~s}$ are not directly comparable) and indicates the added impact of the usefulness of training. It reinforces that if training is not perceived to be useful then the positive impact of training on confidence is completely absent, consistent with our earlier proposition 2 . 
Table 7 Union contact and support, mentoring, role clarity, tenure and training issues on delegate confidence

\begin{tabular}{|c|c|c|}
\hline & $\begin{array}{l}\text { Confidence } \\
\text { (RORP) }\end{array}$ & $\begin{array}{l}\text { Confidence } \\
\text { (RORP) }\end{array}$ \\
\hline Constant & $\begin{array}{l}3.182^{\star \star *} \\
(97.82)\end{array}$ & $\begin{array}{l}3.381^{* * *} \\
(51.37)\end{array}$ \\
\hline Organiser contact (high) & $\begin{array}{l}0.246^{\star \star \star} \\
(6.41)\end{array}$ & $\begin{array}{l}0.222^{* * *} \\
(5.50)\end{array}$ \\
\hline Union office support (high) & $\begin{array}{l}0.124^{\star * *} \\
(3.71)\end{array}$ & $\begin{array}{l}0.084^{*} \\
(2.21)\end{array}$ \\
\hline Union office contact (high) & $\begin{array}{l}0.138^{* *} \\
(2.83)\end{array}$ & $\begin{array}{l}0.149 * * \\
(2.88)\end{array}$ \\
\hline Organiser mentoring (agree) & $\begin{array}{l}0.199^{\star * *} \\
(5.90)\end{array}$ & $\begin{array}{c}0.181^{* * *} \\
(4.76)\end{array}$ \\
\hline Role clarity (agree) & $\begin{array}{l}0.468^{* * *} \\
(12.91)\end{array}$ & $\begin{array}{l}0.399 * * * \\
(8.57)\end{array}$ \\
\hline Tenure (per 5 years) & $\begin{array}{l}0.101^{* * *} \\
(7.87)\end{array}$ & $\begin{array}{l}0.103^{* * *} \\
(7.30)\end{array}$ \\
\hline Training index (per issue) & $\begin{array}{l}0.038^{* * *} \\
(6.02)\end{array}$ & $\begin{array}{l}0.034^{* * *} \\
(3.30)\end{array}$ \\
\hline $\begin{array}{l}\text { Usefulness of training - Rating: Not } \\
\text { useful (1) to (3)§ }\end{array}$ & & $\begin{array}{l}-0.216^{* * *} \\
(-4.34)\end{array}$ \\
\hline $\begin{array}{l}\text { Usefulness of training - Rating: (4) } \\
\S\end{array}$ & & $\begin{array}{l}-0.093^{*} \\
(-2.36)\end{array}$ \\
\hline $\begin{array}{l}\text { Usefulness of training } \\
\text { Joint F-test ( } \mathrm{df}=2,1434)\end{array}$ & & $9.44^{* * *}$ \\
\hline Adjusted R2 & 0.263 & 0.239 \\
\hline $\mathrm{N}$ & 2305 & 1444 \\
\hline
\end{tabular}

Source: RORP delegate survey

Notes: The table shows the marginal effect of each variable on the confidence index for the units shown in the left hand column. The marginal effects were significant at $5 \%\left(^{*}\right)$ level, $1 \%\left({ }^{* *}\right)$ level and $0.1 \%(* *)$ levels.

t-statistics shown in parentheses.

$\S$ Reference group for this variable is 5 (very useful) 
Again, the findings are reinforced by other surveys. For example, the ECC training participants survey found that delegates who described their organiser as 'very effective' (1, on a 1 to 5 scale) in teaching them valuable things about being a delegate were nearly three times as likely to report that member success had gone up 'a lot' than those who rated their organisers medium to low (between 3 and 5).

\section{Are delegates exhausted by all this training?}

In RORP, delegates who had been trained were more likely than untrained delegates to say that the range of tasks they undertook had widened over the preceding two years (48 per cent of trained said this, versus 32 per cent of untrained delegates). Trained delegates were also more likely to say that their role had become more difficult (33 per cent versus 26 per cent amongst untrained delegates).

However, trained delegates were much more likely to say that they were more satisfied with being a delegate than two years earlier (31 per cent versus 19 per cent) and to agree that they enjoyed being a delegate (73 per cent versus 51 per cent). They also were more likely to demonstrate efficacy (Bandura, 1997) through believing that they could really make a difference at their workplace (73 per cent versus 56 per cent). In the survey of Union A, delegates were considerably more likely to report an increase in satisfaction where they had been followed up after training (58 per cent reported an increase) than where they were not followed up (39 per cent). 
So, yes, training means delegates do more things and more difficult things; but it also makes them more satisfied with being a delegate - especially when training is followed up.

\section{Conclusions}

From these several propositions about union training emerge two broad ideas. First, in the context of debates about union renewal, union training indeed matters. It is important: that delegates receive it, to boost their confidence and hence activism; that it is relevant and of high quality; that it covers issues that are important for promoting activism in the workplace; and that organisers are appropriately trained to manage the critical delegate-organiser relationship. At a practical level, if unions wish to recruit more members, it is not sufficient to just train delegates in how to recruit. Workers join unions because ultimately they see the union as possessing some power that they can use to advance their own interests and which is greater than their own power as an individual. Training delegates just on how to recruit does not in itself build up power very far. Training across a range of issues that promote activism (such as in running campaigns, bargaining and developing networks) will build power and improve the ability of the union to recruit. The fact that training has independent effects is also indicated by the fact that training perceived by respondents as having poor quality will be of little, if any, benefit at all - if it is seen as not useful to delegates' situation or circumstance then it can be quite detrimental to confidence. Conversely, trying to train one delegate within a workplace to handle all of the things that unions must do at the workplace may be asking too much. Delegates need to be able to spread the work 
around, individually focusing on the things that they are good at, while ensuring that collectively the workplace unions has all the skills that are necessary to build power.

The second idea is that it is necessary to conceptualise union training as something much broader than what happens in a classroom. Certainly, the classroom matters without it, unions cannot build - but at least as important is what happens outside the classroom, between the union (mostly, the organiser) and the delegate. Classroom training that is not reinforced by application in the workplace, as a result of follow-up undertaken, most likely, by the organiser, will be classroom training that is largely wasted. More broadly, mentoring the organiser provides the delegate is core to developing confidence and skills for activism amongst delegates. Years of experience gained by the untrained delegate are often wasted if they lack the framework and formal skills with which to locate and respond to workplace issues, but it is also the case that classroom training without planned follow up or an effective delegate-organiser relationship is often wasted. Union training encompasses both the formal and the informal, both the classroom and what happens afterwards.

This produces some important practical challenges. With careful planning and research, a training curriculum can be developed, evaluated, improved and implemented as needs be, to teach delegates the things they need to improve their activism. But the informal, often impromptu relationship between the organiser and the delegate is very different to the ordered situation of the classroom. It in turn points to the importance of the union devoting energy and resources to the training of organisers themselves and ensuring that lessons of their training are applied. 
Moreover, there can be structural problems within unions that create barriers to the effective follow-up of delegate training. Often delegate training is undertaken by specialist trainers, who may be employed by the union or a peak council or other body. The person undertaking the classroom training is often not the person who would have the ongoing relationship with the delegate and therefore be likely to undertake followup, or possibly jointly develop an action plan for pursuing a workplace matter identified through classroom training. Often the people concerned are employed in different divisions of the union with different reporting chains. This means problems of communication and accountability in ensuring follow-up. Some unions have begun to adopt innovative approaches to follow-up to try to overcome these difficulties, for example through multiple, alternating sessions and follow-up with reports back. Others have yet to begin.

Together, these findings suggest a number of issues regarding resource allocation, curriculum development, procedure and organisational structure that unions would need to address if they aim to secure the outcomes that union education and training has the potential to deliver.

\section{Acknowledgements}

This publication was supported by grants through the Australian Research Council, projects C00107620 and A79906581. We also wish to acknowledge the support and assistance of the Australian Council of Trade Unions, its Organising and Campaign Centre, Member Connect and constituent unions, with particular thanks to Michael 
Crosby, Jenny Evans and Carol Webb. AWIRS95 was financed and conducted by the then Commonwealth Department of Industrial Relations. 


\section{References}

Briggs, C. (2001). "Australian exceptionalism: the role of trade unions in the emergence of enterprise bargaining." Journal of Industrial Relations 43(1): 27-43.

Bronfenbrenner, K., \& Hickey, R. (2004). Changing to organize: a national assessment of union strategies. In R. Milkman \& K. Voss (Eds.), Rebuilding Labor: Organizing and Organizers in the New Union Movement (pp. 17-61). Ithaca: Cornell University Press.

Carter, B., \& Cooper, R. (2002). The organizing model and the management of change: a comparative study of unions in Australia and Britain. Industrial Relations, 57(4), 712-742.

Clarke, J., Pocock, B., \& Peetz, D. (2005). Delegates are diamonds: Learning from union delegates' experiences in Australia. Adeliade: Labour Studies, University of Adelaide.

Conrow, T., \& Delp, L. (1999). Teaching organzing through workers' experiences. Labor Studies Journal, 24(1), 42-57.

Cooper, R. (2001). Getting organised? A white collar union response to membership crisis. Journal of Industrial Relations, 43(4), 422-437.

Cooper, R. (2002). Commentary on M. Crosby 'Down with the dictator: the role of trade unions in the future'. In R. Callus \& R. Lansbury (Eds.), Working futures: The changing nature of work and employment relations in Australia (pp. 132-135). Sydney: Federation Press.

Crosby, M. (2002). Down with the dictator: the role of unions in the future. In R. Callus \& R. Lansbury (Eds.), Working Futures: The Changing Nature of Work and Employment in Australia (pp. 115-131). Sydney: The Federation Press. 
Crosby, M. (2005). Power at Work: Rebuilding the Australian Union Movement. Sydney: Federation Press.

Fletcher, B., Jr., \& Hurd, R. W. (1998). Beyond the organizing model: the transformation process in local unions. In K. Bronfenbrenner, S. Friedman, R. W. Hurd, R. A. Oswald \& R. L. Seeber (Eds.), Organizing to Win: New Research on Union Strategies (pp. 37-53). Ithaca: ILR Press.

Frege, C. M., \& Kelly, J. (2003). Union Revitalization Strategies in Comparative Perspective. European Journal of Industrial Relations, 9(1), 7-24.

Grabelsky, J., \& Hurd, R. W. (1994, 3-5 January). Reinventing an organizing union: Strategies for change. Paper presented at the Industrial Relations Research Association 46th Annual Meeting, Boston.

Greene, A.-M. and G. Kirton (2002). "Advancing Gender Equality: The Role of WomenOnly Trade Union Education." Gender, Work and Organisation 9(1): 39-59.

Griffin, G., \& Moors, R. (2004). The fall and rise of organising in a blue-collar union. Journal of Industrial Relations, 46(1), 39-52.

Hackett, G. and N. E. Betz (1981). "A Self-Efficacy Approach to the Career Development of Women." Journal of Vocational Behavior 18: 326-339.

Kelly, J. E. (1998). Rethinking Industrial Relations: Mobilization, collectivism, and long waves. London ; New York: Routledge.

Kumar, P., \& Schenk, C. (2006). Union renewal and organisational change: A review of the literature. In P. Kumar \& C. Schenk (Eds.), Paths to union renewal: Canadian experiences (pp. 29-60). Orchard Park, NY: Broadview Press.

Lenney, E. (1977). "Women's self-confidence in achievement settings." Psychological Bulletin 84(1): 1-13. 
Morehead, A., Steele, M, Alexander, M., Stephen, K. \& Duffin, L. (1997). Changes at work: The 1995 Australian Workplace Industrial Relations Survey, Melbourne: Longman. Muir, K. (2008). Worth fighting for: Inside the Your Rights at Work Campaign. Sydney, University of NSW Press.

Newman, M. (1993). The Third Contract: Theory and Practice in Trade Union Training. Sydney, Stewart Victor.

Peetz, D. (2005). "Trend analysis of union membership." Australian Journal of Labour Economics 8(1): 1-24.

Peetz, D. and B. Pocock (2009). "An analysis of workplace representatives, union power and democracy in Australia." British Journal of Industrial Relations 47(4): 623-652.

Peetz, D., C. Houghton and B. Pocock (2005). "Organisers' Roles Transformed? Australian Union Organizers and Changing Union Strategy." Journal of Industrial Relations 49(2): 151-166.

Peetz, D., Webb, C., \& Jones, M. (2002). Activism amongst workplace union delegates. International Journal of Employment Studies, 10(2), 83-108.

Zammit, E., S. Rizzo and J. Vancell (2003). Trade union education and democratic participation: The case of Malta. New Frontiers of Democratic Participation at Work. M. Gold. Burlington, Ashgate: 295-315. 